\title{
Concepções de professores sobre a inclusão de alunos com deficiência visual na Educação Superior
}

\author{
Teacher conceptions on the inclusion of visual disabled \\ pupils in Higher Education
}

\section{Concepciones de profesores sobre la inclusión de alumnos con deficiencia visual em la Educación Superior}

\author{
Joice Fernanda Pinheiro ${ }^{1}$ \\ ORCID: http://orcid.org/0000-0001-6929-8560 \\ Silvana Maria Moura da Silva ${ }^{2}$ \\ ORCID: http://orcid.org/0000-0001-9331-6319
}

\begin{abstract}
Resumo: A inclusão educacional se fundamenta em uma concepção de direitos e valores humanos, agregando inúmeras possibilidades para as pessoas com deficiência, em especial, o acesso e a permanência no âmbito educacional com equidade desde a educação infantil até a educação superior. Este estudo teve como objetivo geral analisar as concepções dos professores em relação à inclusão de alunos com deficiência visual na Universidade Federal do Maranhão. Optou-se pelo método fenomenológico, abordagem quanti-qualitativa, pesquisas documental, descritiva e de campo. Participaram desta pesquisa 16 professores de alunos com deficiência visual, matriculados no ano letivo de 2019 e frequentadores de cursos do Centro de Ciências Sociais da referida universidade no campus Dom Delgado. Na coleta de dados foi utilizada a entrevista semiestruturada, cuja análise se voltou para a seleção do discurso de cada participante, sendo realizada uma análise fenomenológica (redução eidética) em unidades significativas. As concepções dos professores em relação à inclusão do aluno com deficiência visual na universidade selecionada contemplaram o direito ao acesso garantido desse aluno por meio do sistema de cotas, acessibilidade plena desde o ingresso do mesmo até sua permanência e a garantia para desenvolver as suas habilidades pelo potencial cognitivo desse aluno. Concluiu-se que apesar das ações desenvolvidas e dos serviços oferecidos, há necessidade de adequação em relação às acessibilidades arquitetônica, pedagógica e comunicacional para a efetivação da inclusão de alunos com deficiência visual na Universidade Federal do Maranhão.
\end{abstract}

Palavras-chave: Inclusão. Concepção. Docência. Deficiência visual. Educação superior. Diversidade.

\footnotetext{
${ }^{1}$ Mestre em Educação pela Universidade Federal do Maranhão-UFMA. Graduada em Pedagogia pela Universidade Estadual do Maranhão-UEMA (2017). Técnica em Informática pela Universidade Estadual do Maranhão/Uemanet/e-Tec (2015). Atuando principalmente em pesquisas sobre Educação Especial Inclusiva.

2 Possui Pós-Doutorado pelo Departamento de Psicologia da Universidade Federal de São Carlos (2009). Mestrado em Educação Especial (Educação do Indivíduo Especial) pela Universidade Federal de São Carlos (1994). Graduação em Educação Física pela Universidade Federal do Maranhão/UFMA (1987). Professora Associada Nível III do Departamento de Educação Física da UFMA. Professora e Orientadora no Mestrado em Educação da UFMA. Atua nos seguintes temas: Brinquedoteca Hospitalar, Educação Física Hospitalar (Terapia para Enfermos Especiais), Educação Física Adaptada, Primeira infância, Estimulação Precoce, Deficiência Visual.
} 
Abstract: Educational inclusion is based on a conception of human rights and values, adding countless possibilities for people with disabilities, especially access to and permanence in the educational sphere with equity from early childhood education to higher education. This study aimed at analyzing teachers' conceptions regarding the inclusion of visually impaired students at the Federal University of Maranhão. The phenomenological method, quanti-qualitative approach, documental, descriptive and field research were chosen. Sixteen professors from visually impaired students, enrolled in the 2019 school year and attending courses at the Center of Social Sciences of the referred university at the Dom Delgado campus participated in this research. The data collection was based on a semi-structured interview, whose analysis was focused on the selection of each participant's speech, with a phenomenological analysis (eidetic reduction) in significant units. The professors' conceptions regarding the inclusion of the visually impaired student in the selected university contemplated the right to guaranteed access for this student through the quota system, full accessibility from the student's entrance until his/her permanence and the guarantee to develop his/her abilities through the cognitive potential of this student. It was concluded that despite the actions developed and the services offered, there is a need for adequacy in relation to the architectural, pedagogical and communicational accessibilities for the accomplishment of the inclusion of students with visual impairment at the Federal University of Maranhão.

Keywords: Inclusion. Conception. Teaching. Visual impairment. College education. Diversity.

Resumen: La inclusión educacional se fundamenta en una Concepción de derechos y valores humanos, agregando innúmeras posibilidades para las personas que presentan deficiencia, en especial, el acceso y la permanencia en el ámbito educacional con equidad desde la educación infantil hasta la educación superior. Este estudio tuvo como objetivo general analizar las concepciones de los profesores con relación a la inclusión de alumnos con deficiencia visual en la Universidade Federal do Maranhão. Se optó por el método fenomenológico, abordaje cuanticualitativa, investigación documental, descriptiva y de campo. Participaron de esta investigación 16 profesores de alumnos con deficiencia visual, matriculados en el año lectivo de 2019 y frecuentadores de cursos del Centro de Ciencias Sociales de la referida universidad en el campus Dom Delgado. En la colecta de datos fue utilizada la entrevista semiestructurada, cuyo análisis se volcó para la selección del discurso de cada participante, fue realizada un análisis fenomenológico (reducción eidética) en unidades significativas. Las concepciones de los profesores con relación a la inclusión del alumno con deficiencia visual em la universidad seleccionada contemplaron el derecho al acceso garantizado de ese alumno por medio del sistema de cuotas, accesibilidad plena desde el ingreso de este hasta su permanencia y la garantía para desarrollar sus habilidades por el potencial cognitivo de ese alumno. Se concluyó que a pesar de las acciones desarrolladas y de los servicios ofrecidos, hay necesidad de adecuación con relación a las accesibilidades arquitectónica, pedagógica y comunicacional para a efectuación de la a inclusión de alumnos con deficiencia visual en la Universidade Federal do Maranhão.

Palabras-clave: Inclusión. Concepción. Docencia. Deficiencia visual. Educación superior. Diversidad.

\section{INTRODUÇÃO}

A inclusão de alunos com deficiência na Educação Superior tem gerado discussões acerca da efetividade de políticas públicas, que possibilitem o acesso e a permanência deles nos diversos cursos oferecidos pelas universidades públicas. As novas diretrizes e pesquisas em educação indicam claramente que a inclusão na escola visa ao atendimento de todos com qualidade. Tais indicações podem gerar transformações positivas nesse ambiente de ensino, pois na medida em que se ampliam os atendimentos na Educação Básica, a Educação Superior, também, deve fazer o mesmo (MATTOS, 2002). 
Os direitos das pessoas com deficiência são assegurados por dispositivos legais e pelos discursos proferidos, porém o que os garante são as ações práticas e efetivas capazes de concretizar os dispositivos legais e suas deliberações compreendidos nos textos das políticas públicas. Para isto, além de prever, deve-se prover os recursos de toda ordem para assim garantir que esses direitos sejam respeitados (CARVALHO, 2004).

A Política Nacional de Educação Especial na Perspectiva da Educação Inclusiva tem como objetivo assegurar a inclusão escolar dos alunos com deficiência, transtornos globais de desenvolvimento e altas habilidades/superdotação no sistema educacional de ensino, por meio do acesso ao ensino regular desde a educação infantil à educação superior. Além disso, os sistemas de ensino são orientados por essa Política para que a mesma garanta a oferta do atendimento educacional especializado (AEE), mediante a disponibilização de professores qualificados para o mesmo, bem como formação de demais profissionais da educação para a inclusão; as participações familiar e comunitária na inclusão escolar; acessibilidade arquitetônica nos sistemas e meios de transportes, nos mobiliários; acessibilidade comunicacional e implementação das políticas públicas pela articulação intersetorial (BRASIL, 2008). A acessibilidade arquitetônica consiste na eliminação de barreiras físicas e residenciais nos espaços e equipamentos urbanos. A acessibilidade comunicacional compreende a eliminação de barreiras na comunicação interpessoal, escrita e virtual, de modo que sejam disponibilizados em formato acessível a todos, utilizando-se da Libras, Braile e mecanismos digitais (RANGEL, 2015).

Menciona-se a Lei Brasileira de Inclusão (LBI), Lei no 13.146/15 (Estatuto da Pessoa com Deficiência), representando uma grande conquista do século XXI, "destinada a assegurar e a promover, em condições de igualdade, o exercício dos direitos e das liberdades fundamentais por pessoa com deficiência, visando à sua inclusão social e cidadania". (BRASIL, 2015, p. 19). Dessa forma, a prática das matrículas de alunos com deficiência nas universidades está presente no contexto educacional e se encontra pautada em legislações específicas, que garantem a esses alunos a possibilidade de ingresso na Educação Superior. Assim, tem-se o capítulo IV, artigo 28, inciso I e XIII da LBI:

Art. 28. Incumbe ao poder público assegurar, criar, desenvolver, implementar, incentivar, acompanhar e avaliar: 
I - sistema educacional inclusivo em todos os níveis e modalidades, bem como o aprendizado ao longo de toda a vida;

XIII - acesso à educação superior e à educação profissional e tecnológica em igualdade de oportunidades e condições com as demais pessoas. (BRASIL, 2015, p. 34-35).

A política de inclusão brasileira se estende à Educação Superior, sendo que a universidade deve adaptar suas instalações e, também, qualificar o corpo docente, favorecendo o acesso dos alunos com deficiência ao conhecimento, bem como ao aprendizado e à profissionalização (CHAHINI, 2012).

Recentemente, o Decreto no 10.502, de 30 de setembro de 2020 institui a Política Nacional de Educação Especial: Equitativa, Inclusiva e com Aprendizado ao Longo da Vida, direcionada para a implementação de programas e ações voltados para a garantia dos direitos à educação e ao AEE do público-alvo da Educação Especial no território nacional, senso o mesmo constituído por educandos com deficiência, transtornos globais do desenvolvimento e altas habilidades ou superdotação, os quais nas diferentes etapas, níveis e modalidades de educação, em contextos diversos, nos espaços urbanos e rurais, requeiram a oferta de serviços e recursos da educação especial, incluindo-se a garantia da oferta de serviços e de recursos da educação especial aos educandos indígenas, quilombolas e do campo (BRASIL, 2020).

Infere-se que o público-alvo da educação especial definido na Política Nacional de Educação Especial na Perspectiva da Educação Inclusiva foi mantido na nova Política Nacional de Educação Especial. Entretanto, chama-se atenção que embora os educandos indígenas, quilombolas e do campo foram incluídos como beneficiados da oferta de serviços e de recursos da educação especial, os mesmos não pertencem ao público-alvo da Educação Especial, retrocedendo-se, de certa maneira, ao acrescentar dentro da referida Política 2020 outros educandos, que mesmo tendo necessidades educacionais especiais, não foram incluídos na definição de seu público alvo desde 2008.

$\mathrm{O}$ art. $4^{\circ}$ do Decreto ํㅜ 10.502 estabelece sete objetivos da referida Política Nacional de Educação Especial, sendo destacado o seguinte:

II - promover ensino de excelência aos educandos da educação especial, em todas as etapas, níveis e modalidades de educação, em um sistema educacional equitativo, inclusivo e com aprendizado ao longo da vida, sem a prática de qualquer forma de discriminação ou preconceito. (BRASIL, 2020, não paginado).

A Política Nacional de Educação Especial: Equitativa, Inclusiva e com Aprendizado ao Longo da Vida mantém a transversalidade da modalidade de 
educação especial desde a educação infantil até a educação superior, além de defender a inexistência de práticas discriminatórias ou preconceituosas em todas as etapas, níveis e modalidades de educação.

Uma das ações previstas pela nova Política Nacional de Educação Especial compreende a definição de estratégias e de orientações para as instituições de Educação Superior (IES), no sentido de permitir a garantia da prestação de serviços ao público-alvo da educação especial para incentivar projetos de ensino, pesquisa e extensão voltados para a área da educação especial e estruturar a formação de profissionais especializados para o cumprimentos dos seus objetivos (BRASIL, 2020).

O fazer educação para todos implica mudanças no pensar e no sentir, todavia isso não ocorre de um dia para o outro. Por mais incoerentes que sejam as tranformações almejadas para que os sistemas de ensino ofertem educação de qualidade com vias ao atendimeto diversificado, estas não dependem exclusivamente das políticas educacionais, pois elas devem se articular com as demandas das políticas públicas e com os responsáveis pela distribuição dos recursos (CARVALHO, 2004).

Existe, ainda, a necessidade de enfrentar o desafio da democratização do ensino para todas as pessoas. Considera-se que para uma educação inclusiva efetiva se faz necessário compreender questões históricas e culturais envolvidas na organização da sociedade para assim possibilitar melhores condições de vida a todas as pessoas, independentemente de suas condições comuns ou especiais (JESUS, 2012).

Compreende-se, ainda, que a inclusão não deve ocorrer aleatoriamente e que os sistemas de ensino e as escolas, como unidades sociais são organismos vivos e dinâmicos, os quais assim entendidos, tornar-se-ão importantes e significativas células vivas da sociedade, com ela interagindo, a partir da dinâmica de seus múltiplos processos. A reorganização do sistema educacional, na perspectiva inclusiva, aponta para um novo modelo de escola e de professor preparado para atuar frente à diversidade (GIROTO; POKER; OMOTE, 2012).

Portanto, na inclusão se enfatiza o papel do professor, pois ele está diretamente ligado ao ensino e à aprendizagem do aluno, sendo o responsável por sua formação. Existe a necessidade de interação entre professor e aluno, fazendo- 
se necessária para a construção do conhecimento. Sabe-se que no âmbito universitário os processos de ensino e de aprendizagem são ações constantes entre o aluno e o professor, visto a importância da discussão sobre a formação desse último para a promoção de uma educação inclusiva (FACHINETTI, 2018).

Ressalta-se que a promoção da inclusão na Educação Superior necessita de recursos materiais, estruturais e financeiros, que por sua vez implicam em acessibilidades arquitetônica, pedagógica, comunicacional, atitudinal, de materiais didáticos adaptados, profissionais capacitados e atitudes inclusivas. No entanto, para que o processo aconteça, nesse âmbito, julga-se imprescindível o professor como agente transformador dos processos de ensino e de aprendizagem do aluno. As concepções do professor e o modo como realiza seu trabalho, ainda, que não disponha de recursos adequados, constituem-se em fatores fundamentais para a promoção da inclusão do aluno com deficiência (PINHEIRO, 2017; FACHINETTI, 2018).

As pessoas com deficiência visual têm determinadas limitações, necessitando de suporte adequado para o desenvolvimento de seu aprendizado e o professor é essencial para o progresso da aprendizagem. É de suma importância saber quais são as concepções dos docentes em relação à inclusão de alunos com deficiência visual na Educação Superior na Universidade Federal do Maranhão (UFMA).

Ressalta-se que para compreender as concepções docentes é necessário considerar a percepção e o saber de suas experiências. Por isso, é necessário compreendê-los como seres inteiros, capazes de dar sentido ao mundo, conscientes de que o mundo não é somente uma coleção de circunstâncias estudadas pelas ciências. Como seres culturais, criam-se as relações sociais e como seres sociais são compreendidos por meio do convívio com as outras pessoas (MAGALHÃES, 2016).

Considerando o papel do professor no processo educativo, tem-se o seguinte problema central de pesquisa: Quais as concepções dos professores em relação à inclusão de alunos com deficiência visual na Ufma? Esta pesquisa teve como objetivo geral: Analisar as concepções dos professores em relação à inclusão de alunos com deficiência visual na Ufma. 


\section{INCLUSÃO EDUCACIONAL DO ALUNO COM DEFICIÊNCIA VISUAL NA EDUCAÇÃO SUPERIOR}

A preocupação em relação ao acesso e a permanência de alunos com deficiência na Educação Superior teve início em meados dos anos 90 constituindo, assim, uma temática crescente e de grande importância paras as sociedades democráticas, que visam à equidade, à solidariedade e o respeito à diversidade. Esses novos valores e concepções têm contribuído para a fomentação de um grande número de leis tanto em nível nacional quanto internacional sobre a inclusão das pessoas com deficiência na Educação Superior. Do mesmo modo, existe um atraso significativo na produção de normas especificas, que deem suporte à pessoa com deficiência na Educação Superior (RAMA, 2006).

No Brasil, a Educação Superior é acessível para poucos. Os extratos minoritários da população, bem como negros, quilombolas, indígenas e pessoas com deficiência, ainda, têm dificuldades para o acesso a esse nível de ensino. De acordo com a narrativa histórica essa exclusão ocorre desde a implantação tardia da Educação Superior no Brasil pela resistência de Portugal a tal pleito, sendo que os filhos das elites brasileiras estudavam na Europa (MAGALHÃES, 2006).

Existem, ainda, desigualdades marcantes em relação ao ingresso de pessoas excluídas socialmente na Educação Superior, podendo ter relação com a discrepância entre as realidades individuais. Para buscar soluções se faz necessário conhecê-las e desvelar injustiças, incentivando a construção de políticas públicas voltadas para a equidade. Para Rama (2006, p. 8), “[...] este não é apenas um problema de acesso, permanência, saída, direitos humanos ou como as universidades estão reestruturando e transformando sociedades, mas também inclui práticas culturais fortemente enraizadas de marginalização e exclusão social".

A universidade deve oferecer condições de acesso e permanência para a pessoa com deficiência na Educação Superior, tratando-se de um direito dela enquanto cidadã. Os docentes muitas vezes se sentem despreparados para trabalhar com a diversidade, sendo necessárias ações, que visem à formação profissional para inclusão (PASSOS, 2013).

A legislação brasileira vem avançando, consideravelmente, em relação aos direitos das pessoas com deficiência, não se limitando apenas à Educação Básica, mas ampliando-se à Educação Superior. Na Constituição Federal de 1988, o artigo 
205 destacou a educação como um direito de todos, garantindo o pleno desenvolvimento da pessoa, o exercício da cidadania e a qualificação para o trabalho (BRASIL, [2016]).

Percebe-se que a educação brasileira, como um todo, vai conquistando evidências nas discussões sociais e, de forma específica, a Educação Especial, a partir de 1996, com a aprovação da Lei de Diretrizes e Base da Educação Nacional (LDB), Lei no 9.394/96. A LDB de 1996, que no Capítulo V dispõe as diretrizes específicas da Educação Especial, reconhecendo-a como modalidade de educação escolar, devendo ser ofertada, preferencialmente, na rede regular para alunos com deficiência (BRASIL, 1996a).

O Aviso Circular no 277/MEC/GM - Brasília, de 08 de maio de 1996 trouxe recomendações para que as Instituições de Ensino Superior (IES) criem condições de acesso e permanência aos estudantes com deficiência nos cursos oferecidos pelas mesmas. Esse documento demonstrou a preocupação com o processo seletivo, sua flexibilização e, também, com a capacitação de recursos humanos e mudanças na infraestrutura capazes de contribuir para a permanência dos estudantes nos cursos (BRASIL, 1996b).

Nota-se que as universidades públicas, nas últimas décadas, têm desenvolvido pesquisas e ações direcionadas à promoção da inclusão de alunos com deficiência em todo território nacional. Considerando as normas nacionais da inclusão educacional de pessoas com deficiência, tais universidades passaram a desenvolver ações de combate à exclusão, orientadas por dispositivos como a Portaria $\mathrm{n}^{\circ} 1.679 / 99$. Nessa portaria o art.1ํㅜ,

\begin{abstract}
Determina que sejam incluídos nos instrumentos destinados a avaliar as condições de oferta de cursos superiores, para fins de credenciamento de instituições de ensino superior, bem como para sua renovação, conforme as normas em vigor, requisitos de acessibilidade de pessoas portadoras de necessidades especiais. (BRASIL, 1999, p. 1).
\end{abstract}

Ressalta-se que essa Portaria prevê o estabelecimento de requisitos de acessibilidade para pessoas com deficiências física, visual e auditiva pela Secretaria de Educação Superior do Ministério da Educação (BRASIL, 1999), com apoio técnico da Secretaria de Educação Especial, tendo como referência à Norma Brasileira ABNT NBR 9050, da Associação Brasileira de Normas Técnicas (2004) sobre a Acessibilidade de Pessoas Portadoras de Deficiências e Edificações, Espaço, Mobiliário e Equipamentos Urbanos. 
A Lei $\mathrm{n}^{0}$ 10.098, de 19 de dezembro de 2000 estabeleceu normas gerais e critérios básicos para a promoção da acessibilidade das pessoas portadoras de deficiência ou com mobilidade reduzida, visando alcançar o acesso desses indivíduos, mediante a supressão de barreiras e de obstáculos nas vias e espaços públicos, no mobiliário urbano, na construção e reforma de edifícios e nos meios de transporte e de comunicação (BRASIL, 2000b).

Quanto à acessibilidade na Educação Superior, a Portaria no $3.284 / 03$ reiterou orientações sobre os requisitos necessários para instruir os processos de autorização e de reconhecimento de cursos e de credenciamento de IES (BRASIL, 2003). A legislação brasileira específica para a acessibilidade à educação superior foi pioneira, tendo em vista a existência de um vasto repertório jurídico com essa finalidade, sendo possível ser acionado juridicamente com o não cumprimento desses requisitos (MANZINI, 2008).

O Decreto $n^{\circ}$ 5.296/04 regulamentou as Leis $n^{\circ}=10.048 / 2000$ que dá prioridade de atendimento às pessoas que especifica (BRASIL, 2000a) e a Lei no 10.098/2000 que estabelece normas gerais e critérios básicos para a promoção da acessibilidade das pessoas portadoras de deficiência ou com mobilidade reduzida, e dá outras providências (BRASIL, 2000b).

A acessibilidade ocorre quando são dadas às pessoas com deficiência ou mobilidade reduzida, condições para que utilizem com segurança e autonomia, total ou assistida, os espaços urbanos, as edificações, os serviços de transportes, dispositivos, sistemas e meios de comunicação e informação (RANGEL, 2015).

A universidade deve ofertar condições de acessibilidade, pois assim estará adequada para que os alunos com deficiência possam ter acesso à mesma de forma mais equitativa. Os tipos de acessibilidade são um requisito legal para que as IES se comprometam a garanti-los ao aluno com deficiência, de modo que estejam alinhados ao projeto pedagógico da instituição, pois a diversidade humana deve ser atendida. A acessibilidade não se restringe apenas a aspectos físicos e estruturais, mas observá-la em todas as dimensões da instituição para que assim exista processo de inclusão efetivo (RANGEL, 2015).

Em 2004 foi lançado e implementado, em cumprimento ao Decreto Presidencial no 5.296, o Programa Incluir, desenvolvido pela Secretaria de Educação Superior (SESu) em parceria com a Secretaria de Educação Especial (Seesp), tendo 
como objetivo incluir alunos com deficiência na Educação Superior. O Programa Incluir visa romper com os contextos excludentes na Educação Superior, buscando promover uma educação de qualidade, financiando projetos pata garantir a inclusão das pessoas com deficiência no ambiente acadêmico, rompendo as barreiras, sejam elas comportamentais, arquitetônicas, pedagógicas ou comunicacionais, bem como a implantação dos Núcleos de Acessibilidade nas universidades federais (BRASIL, 2004).

Existe, ainda, o Decreto $n^{\circ} 7.611 / 11$ sobre o AEE pressupondo a estruturação de Núcleos de Acessibilidade nas IES, pois "[...] visam eliminar barreiras físicas, de comunicação e de informação que restringem a participação e o desenvolvimento acadêmico e social de estudantes com deficiência." (BRASIL, 2011, p. 2). Observase que o Decreto nำ7.611/11 visa à estruturação dos núcleos de acessibilidade nas IES para eliminar as barreiras, que reduzem a participação, os desenvolvimentos acadêmico e social de estudantes com deficiência, transtornos globais do desenvolvimento e altas habilidades/superdotação. (JESUS, 2020).

Pereira (2017) estudou o processo de inclusão de discentes com deficiência Ufma, focado nos serviços de apoio do Núcleo de Acessibilidade, o Nuaces, o qual vem atuando como articulador das ações a favor das pessoas com deficiência. Ressaltou, ainda, que é por meio do núcleo que ocorre a instrumentalização da política da educação especial na perspectiva inclusiva e, assim, ela amadurece e se materializa no contexto da universidade. É preciso que o acesso à Educação Superior, apesar de toda contradição que permeia a sociedade capitalista, seja reconhecido e faça parte de uma política que garanta os direitos sociais tanto de pessoas com deficiência como de outros segmentos excluídos historicamente do processo educacional.

Assim, o papel da universidade torna-se fundamental, não podendo ser indiferente à diversidade, visto existir a necessidade de buscar um processo educacional justo e democrático. É necessário que o Estado assuma essa dívida histórica, no que concerne à educação das pessoas com deficiência. Porém, se a legislação e as normas não sanarem tal problemática, faz-se necessário que as políticas públicas invistam, também, na qualificação dos professores e nos recursos, cuja finalidade é a garantia de acesso e permanência das pessoas com deficiência na Educação Superior (ROCHA; MIRANDA, 2009). 
Em se tratando da inclusão de alunos com deficiência visual na Educação Superior para que esses estudantes consigam ter acesso, é necessário que se apropriem dos conhecimentos socioculturais produzidos desde a Educação Básica, pois é fundamental a aquisição e a operacionalização de recursos materiais especializados, como no mínimo: materiais didáticos em Braile e com fontes ampliadas, além da presença desses recursos no processo seletivo vestibular (CHAHINI, 2016). Nesse sentido "[...] talvez em nenhuma outra forma de educação os recursos didáticos assumam tanta importância como na Educação Especial de pessoas com deficiência [...]" (CERQUEIRA; FERREIRA, 2000, p. 24).

Para Mantoan (2007) quando o aluno com deficiência é inserido dentro do contexto educacional junto com os demais alunos, tendo o mesmo acesso para transitar dentro do sistema educacional, ocorre uma integração do mesmo. Acrescentou, ainda, que a integração não é incompatível com a inclusão, mas a inclusão ocorre em seu sentido mais completo e sistemático, pois abrange as vidas social e educativa de todos os alunos, que devem ser incluídos, de modo que thes sejam ofertadas todas as condições necessárias ao seu aprendizado, como, por exemplo, a acessibilidade plena em todos os âmbitos da instituição.

Pieczkowski (2014) enfatizou que o professor ao ter um aluno com deficiência em sala, faz uma busca individual por metodologias para Ihe auxiliarem no ensino e na aprendizagem do mesmo. É compreensível o professor ser acometido por certa ansiedade e desconforto, quando se depara com um aluno nessas condições pela necessidade de apresentar formação específica e saberes essenciais para fundamentar sua prática.

A seleção para o ingresso do aluno com deficiência visual na Educação Superior, deveria envolver algumas ações por parte dos gestores da instituição, bem como entrar em contato com o candidato para saber quais as suas necessidades, quais os instrumentos a serem disponibilizados, tais como tempo e o formato da prova, o ledor ou outro suporte para garantir seu direito de concorrer com equidade com os outros. Diferentes propostas devem ser adotadas para oportunizar o acesso à Educação Superior com qualidade, bem como estratégias de permanência, iniciando com a identificação desses alunos na universidade, julgando-se como um ato necessário para que assim a instituição possa oferecer serviços a esses alunos (SILVA JÚNIOR; HAMMES, 2014). 
A inclusão está relacionada a um conjunto de ideias e ações, que combinadas entre si, podem produzir a materialização da mesma sem exceções, discriminações ou esquivos e é nessa concepção que se pode afirmar sua complexidade, mas não utópica, ou seja, a inclusão é a materialização da mais genuína humanização (ORRÚ, 2017). Nesse sentido, a inclusão é um processo que vai para além da valorização da diversidade (COUTINHO, 2011). Entretanto, ao ter acesso à Educação Superior se faz necessário que as universidades, também, ofereçam as condições básicas para que o aluno se desenvolva e consiga concluir o seu processo formativo com êxito e de posse dos conhecimentos indispensáveis para o mercado de trabalho (COUTINHO, 2011; SOARES, 2011; JESUS, 2012; CABRAL, 2018).

As políticas públicas para o acesso e a permanência na Educação Superior de alunos com deficiência visual não garantem por si só a efetivação, mas há necessidade de que as mesmas esclareçam como as universidades devem realizar esse processo (MOREIRA, 2012). Ressalta-se que as políticas devem ir além dos dispositivos do Programa Incluir, sendo uma política que foca na articulação das IES para uma proposta inclusiva, viabilizando meios para realização de ações nesse ambiente (SILVA JÚNIOR; HAMMES, 2014).

Em relação à política de inclusão na Educação Superior, é necessário promover ações, como a adaptação do vestibular, modificação de sua estrutura física e a contratação de profissionais capazes de atender às pessoas com deficiência, bem como a criação de um núcleo de acessibilidade. Todavia, foi percebida a necessidade de haver maior articulação entre os envolvidos no processo inclusivo (BREDA, 2013). Dantas (2017) ressaltou a necessidade de equipar as instituições de educação superior com recursos tanto orçamentários quanto humanos para cumprimento das determinações legais e, assim, operacionalizá-las, pois o que geralmente contribui para a ineficácia de ações dessa natureza é a falta de condições para prover as ações necessárias. Portanto, a sociedade não deve culpar somente a instituição por não está ofertando aos alunos com deficiência o atendimento educacional adequado pela indisponibilidade dos materiais adaptados, não conseguindo promover uma inclusão de forma eficaz.

Em relação à efetividade nas políticas públicas de inclusão, depreende-se a necessidade de os dirigentes considerarem os grupos minoritários e suas 
necessidades para que, assim, possam ocorrer o respeito e a dignidade humana. Para isto, é necessário considerar as relações entre as pessoas, de modo que se reconheça que aquelas com deficiência visual são capazes de aprender e produzir, a partir da efetivação de seus direitos (COUTINHO, 2012).

Quando se discute sobre a efetividade da inclusão, percebe-se que a mesma está diretamente relacionada a todos os setores sociais, devendo-se considerar a pessoa com deficiência como um sujeito de direitos.

Cabe lembrar que uma sociedade inclusiva tem o compromisso com as minorias e com as pessoas com deficiência. A inclusão social é, na verdade, uma medida de ordem econômica, uma vez que a pessoa com deficiência e outras minorias se tornam cidadãos produtivos, participantes, conscientes de seus direitos e deveres, diminuindo, assim, as demandas sociais. (PIMENTA, 2017, p. 71).

Quando os alunos com deficiência visual adentrarem na IES, é pertinente que os professores tenham conhecimento de suas especificidades, além de serem orientados para trabalhar com eles. Com as devidas instruções, devem procurar adaptar suas aulas e buscarem apoio da instituição para, assim, desenvolverem estratégias metodológicas adequadas para esses alunos. As informações visuais devem ser descritas mediante a oralidade. Por sua vez, o aluno com deficiência visual deverá estar posicionado em um local na sala de aula, que favoreça a sua audição e compreensão da aula. (MASINI; BAZON, 2005).

Comenta-se que a inclusão educacional de pessoas com deficiência visual está diretamente ligada à inclusão social e deve contribuir para que as demais pessoas adotem uma postura reflexiva e, assim, possam entender, valorizar e respeitar as diferenças, buscando caminhos para que a inclusão ocorra em sua efetividade. Que esse movimento inclusivo faça parte do cotidiano das pessoas da comunidade acadêmica nas IES (COSTA, 2007; GIROTO; POKER; OMOTE, 2012).

Posto isto, destaca-se que dentre as propostas sobre a superação de barreiras para os alunos com deficiência visual e qualquer outra deficiência, as IES devem definir em suas políticas institucionais estratégias com a proposição de sanar as lacunas existentes para a inclusão desses alunos. Além de propor estratégias, existe a necessidade de sua operacionalização, onde cada membro da comunidade escolar faça a sua parte e ao mesmo tempo trabalhe uns com os outros em busca desse objetivo comum. 


\section{POLÍticas de AÇÕES AFIRMATIVAS NA EDUCAÇÃo SUPERIOR PARA PESSOAS COM DEFICIÊNCIA}

Surge em meados do século XX o termo "Ações Afirmativas" nos Estados Unidos da América (EUA) com o intuito de expandir as oportunidades para os que se encontravam em situação de vulnerabilidade social, em um cenário histórico e conflituoso dos negros, que lutavam contra o racismo (BRANDÃO, 2005). Com o avanço do tempo, o público a que se destina essas ações foi se expandindo. As políticas de ações afirmativas historicamente são atribuídas para combater as desigualdades existentes na sociedade, tendo como objetivo diminuir a exclusão social (JESUS, 2020).

A universidade é um ambiente no qual os indivíduos das mais diversas classes sociais se encontram e penetram em cenários de concorrência e de conflito, a partir do seu acesso até sua permanência. O universo da Educação Superior é um ambiente de trocas de comunicação, de interação e tem recebido alunos de seguimentos minoritários, que antes eram excluídos dessa modalidade (OLIVEIRA, 2011).

O combate às injustiças praticadas em nosso país, produzidas pela discriminação e pelo preconceito, demanda a implementação de ações e de políticas mais efetivas. As políticas afirmativas aparecem neste contexto como uma das alternativas que precisam ser debatidas e experimentadas. (PANIZZI, 2004, p. 7).

Desse modo, as ações afirmativas constituem um conjunto de políticas de caráter compulsório, facultativo ou voluntário, tendo por objetivo combater toda e qualquer forma de discriminação praticada no passado, bem como favorecer e proteger as minorias sociais, visando à garantia dos direitos humanos. Para tanto, visa à concretização do ideal de efetiva equidade a bens fundamentais, como educação e emprego para populações com menor renda e em situações críticas (OLIVEIRA, 2011; PROGRAMA DAS NAÇÕES UNIDAS PARA O DESENVOLVIMENTO, 2005).

Ao falar de igualdade e de diversidade, entende-se que igualdade se trata de um princípio universal, tendo mesmo significado de equidade, justiça, garantia de direitos fundamentais e garantia da dignidade como pessoa humana. $O$ entendimento de diversidade está relacionado às particularidades e diferenças de 
cada pessoa nos mais diversos aspectos, sejam eles físicos, psicológicos ou culturais (LIMA, 2006).

[...] a essas diversidades - digamos, construtivas - soma-se uma diversidade ou uma diferença negativa para maior parte da humanidade: a desigualdade social, termo que se refere, também na forma dicionarizada, ao que é parcial, injusto. Essa desigualdade, marcada por diferenças de classe social e de poder econômico e político, associa-se a uma visão ingênua, às diversidades nos aspectos físico, psicológico e cultural, levando à quebra do princípio universal da igualdade entre humanos. (LIMA, 2006, p. 21).

Compreende-se que ao propor a inclusão para todos como cidadãos, que possam participar das produções social, econômica e cultural da sociedade, enfatiza-se a igualdade efetiva entre as pessoas, reconhecendo as suas diferenças em seus aspectos e particularidades. Desse modo, a diversidade não se opõe à igualdade, pois o que concede a ideia de oposição entre esses termos é a desigualdade ser construída socialmente, uma vez que esta supõe que um vale mais que o outro. Assim, a luta frente a essa contradição é uma proposta a ser superada pela educação inclusiva (LIMA, 2006).

Ressalta-se que a inclusão está relacionada a um conjunto de ideias e ações, que combinadas entre si, podem produzir a materialização da mesma sem exceções, discriminações ou esquivos e é nessa concepção que se pode afirmar sua complexidade, mas não utópica, ou seja, a inclusão é a materialização da mais genuína humanização (ORRÚ, 2017).

No universo educacional brasileiro em 1988, por meio da Constituição da República Federativa do Brasil, foi preconizada a garantia do acesso em todos os níveis de ensino. Dessa forma, nos anos seguintes foi percebido um crescimento de ações e de debates, dos quais envolviam a aplicação e a diversificação do sistema (CABRAL, 2018). Isto foi notável, devido à criação de cursos sequenciais e alternativos, como por exemplo,

[...] o vestibular aberto pela LDB (Lei $n^{\circ}$ 9.394/96); pelo novo programa de crédito educativo (FIES); pela pressão exercida por grupos historicamente excluídos do Ensino Superior - mediante movimentos de isenção da taxa de inscrição para o vestibular e da experiência dos cursos pré-vestibulares alternativos - ; e ainda pela introdução do sistema de cotas para alunos negros e outros, oriundos de escolas públicas, como nova forma de acesso à educação superior. (DOURADO; CATANI; OLIVEIRA, 2004, p. 101-102).

Compreende-se que as políticas de cotas integram um tema complexo, por ter relação com interesses de grupos sociais e raciais e em virtude de diferenciados 
pontos de vista e juízos, além de se envolver diretamente nas tramas discursivas que visam atravessar preconceitos, mediante as políticas de ações afirmativas (CAVALCANTE, 2015). Nesse contexto, os alunos com deficiência para terem acesso à Educação Superior por meio do sistema de cota, poderão enfrentar uma visão social com conotações de piedade, comiseração ou pena, além de porventura se depararem com manifestações de ignorância, indiferença e até mesmo preconceito (PEREIRA, 2008; ANSAY, 2010; CABRAL, 2017).

Nos anos 2000, as políticas voltadas para Educação Superior retomaram as discussões da educação como um direito social, ocorrendo investimentos para a expansão do setor público federal, sendo que as universidades e institutos federais ofereceriam mais vagas e adotariam políticas de ações afirmativas, como o sistema de cotas ou reserva de vagas e bonificação. Tais ações e propostas foram frutos de movimentos sociais de reconhecimento das diferenças de identidades embasadas pelos direitos humanos (CAVALCANTE, 2015).

Em relação à normatização da inclusão de pessoas com deficiência, a partir dos anos 2000 o Brasil buscou legitimar a garantia da educação a essas pessoas em todos os níveis de ensino, por meio de ações e programas governamentais. No que tange às primeiras ações desse período (2000) podem ser destacadas: a Lei no 10.436, de 2002, que dispõe sobre a Língua Brasileira de Sinais (Libras) e suas providências (BRASIL, 2002); a Portaria no 3.284, de 2003, que dispõe sobre requisitos de acessibilidade de pessoas portadoras de deficiência para instruir os processos de autorização e de reconhecimento de cursos, e de credenciamento de IES (BRASIL, 2003). Contudo, merecem destaque, ainda, documentos que normatizam a inclusão de alunos com deficiência na Educação Superior, bem como - Programa Incluir (2005) e a Política Nacional de Educação Especial na Perspectiva da Educação Inclusiva (2008) (CABRAL; MELO 2017).

No que concerne à implantação e incorporação de sistemas de cotas em universidades brasileiras, a participação do Brasil na Conferência Mundial de Durban na África do Sul em 2001 foi importante para essas ações, assim como de vários documentos, que apresentam os direitos humanos. Dessa forma, o Brasil se comprometeu a adotar medidas, visando à eliminação de barreiras, de preconceitos e falta de oportunidades que assolavam a população brasileira (CAVALCANTE, 2015). 
A partir de então, no decorrer dos anos 2000, as primeiras experiências brasileiras em relação ao sistema de cotas nas universidades tiveram início na esfera estadual em 2002 na Universidade Estadual do Rio de Janeiro (Uerj), na Universidade Estadual do Norte Fluminense (Uenf) e em âmbito federal na Universidade de Brasília (UNB) em 2003.

Em 2005, por meio da SESu e Seesp, o Ministério da Educação (MEC) criou o Programa Incluir com a finalidade de garantir o direito à Educação Superior para pessoas com deficiência e o cumprimento dos requisitos legais relativos à acessibilidade em conformidade com o Decreto Presidencial № 5.296 de 2004. O Programa Incluir dava apoio a projetos de IES, que se destinassem à garantia do acesso e da permanência para alunos com deficiência, propondo que as universidades elaborassem seus projetos com a finalidade de atuarem na diminuição de desigualdades (OLIVEIRA, 2011).

No âmbito da Ufma, as Unidades Acadêmicas em conjunto com o Núcleo de Estudos Afro-Brasileiros e com movimentos sociais locais, discutiram e aprovaram por meio da Comissão Permanente de Vestibular (Copeve) um Programa de Ação Afirmativa de cotas para alunos negros, indígenas, deficientes e de escolas públicas, entrando em vigor a partir do processo seletivo de 2007 (CHAHINI, 2013).

Por meio da Resolução no 121 do Conselho Universitário (Consun), em 17 de dezembro de 2009, foi aprovado pela Ufma a criação de um Núcleo PróAcessibilidade e Permanência de Pessoas com Deficiência à Educação, cabendo a esse Núcleo garantir o ingresso e acesso ao conhecimento às pessoas com deficiência na Universidade, mediante suporte técnico e atendimento educacional especializado (CHAHINI, 2013).

Apesar da existência de ações voltadas à inclusão do aluno com deficiência, foi por meio da Lei no 13.409/2016 que o sistema de cotas para pessoas com deficiência foi implementado, estabelecendo que as instituições educacionais devam reservar vagas para esses alunos em cursos de nível técnico, médio e superior (BRASIL, 2016). Essa lei vem apenas acrescentar as pessoas com deficiência, uma vez que na Lei no 12.711/2012 anterior a essa não tinha especificação sobre as mesmas. Para Jesus (2020), a lei de Cotas no 12.711/12 garantia um percentual de $50 \%$ de vagas por curso e turno nas IES para alunos do ensino médio público. 
A Ufma incluiu em seu Projeto Pedagógico Institucional responsabilidades e ações para a inclusão na Educação Superior. A Resolução no 121, de 17 de dezembro de 2009 instituiu o Nuaces, cujo funcionamento efetivo só ocorreu em 2010 voltado para garantir o acesso, a permanência e a conclusão do curso de alunos com deficiência, dispondo de serviços técnicos e profissionais especializados (UNIVERSIDADE FEDERAL DO MARANHÃO, 2009).

Sabe-se que assim como a Educação Básica, a Educação Superior, também, enfrenta desafios relacionados à inclusão de alunos com deficiência, existindo a necessidade de serem trabalhadas questões sobre as barreiras, que causam impedimento no exercício da cidadania desses alunos, bem como as barreiras arquitetônicas, de comunicação e informação, atitudinal, pedagógica, entre outras. Nesse contexto de concretização das inclusões social e educacional, o Nuaces busca "[...] organizar ações de sensibilização e capacitação, por considerar que estas são essenciais na formação de uma nova cultura universitária, pautada no respeito mútuo e no combate a qualquer tipo de discriminação contra as pessoas com deficiência [...]" (PEREIRA, 2017, p. 21). Destaca-se que embora os documentos institucionais da Ufma se refiram ao Nuaces, em meados de 2019, ocorreu uma mudança em relação a denominação do mesmo, passando a ser Diretoria de Acessibilidade (Daces).

A responsabilidade na oferta de AEE e de acompanhamento dos alunos com deficiência ingressantes na Ufma foi desenvolvida, por meio do sistema de cotas para pessoa com deficiência, em consonância com a Resolução nº 499/06, do Conselho de Pesquisa e Extensão (Consepe), de 31 de outubro de 2006 e que abrange, também, os alunos negros, indígenas e estudantes de escolas públicas (UNIVERSIDADE FEDERAL DO MARANHÃO, 2006; PEREIRA, 2017).

O Plano de Desenvolvimento Institucional (PDI) dispõe de estratégias e ações que viabilizem melhoria na acessibilidade, bem como proporcione a permanência e recursos necessários tanto para os alunos com deficiência quanto para os professores, a fim de propiciar um ensino de qualidade e com êxito (UNIVERSIDADE FEDERAL DO MARANHÃO, 2016).

As políticas de caráter compensatório e de emancipação, assim como as ações afirmativas são necessárias e indispensáveis em países como o Brasil, que tem como herança grandes problemas sociais provenientes de uma estrutura 
econômica, uma vez que fora baseada no trabalho escravo em uma sociedade colonialista. Ressalta-se, ainda, que as políticas públicas voltadas para a proteção social são cada vez mais essenciais às ações governamentais em seus diferentes graus para não perder de vista a responsabilidade cívica do Estado, bem como suas obrigações éticas para formar cidadãos capazes de produzir e reproduzir suas relações individuais, pessoais e sociais (PEREIRA, 2008).

Nessa conjuntura, deve-se promover os direitos das pessoas com deficiência, sabendo que estas por muito tempo enfrentaram as mais diversas formas de discriminação, visto que dispor dessas ações é uma importante aliada na garantia dos seus direitos como seres humanos (CARDOSO, 2012).

\section{DESENVOLVIMENTO}

A pesquisa foi aprovada, mediante o parecer consubstanciado $\mathrm{n}^{0} 3.593 .207$ para atender as determinações da Resolução CNS n $510 / 16$ e outras relacionadas ao Conselho Nacional de Saúde para pesquisas contendo seres humanos.

Optou-se pelo método fenomenológico, abordagem quanti-qualitativa, pesquisas documental, descritiva e de campo. Ao utilizar esse método, o pesquisador rompe com a pretensa neutralidade científica, visto que aponta caminhos a serem construídos pelo processo investigativo ou partirá de caminhos anteriormente conhecidos no que diz respeito às práticas sociais e ações compreendidas (KLÜBER; BURAK, 2008).

Os participantes desta pesquisa foram 16 (dezesseis) professores universitários (PU), de alunos com deficiência visual, matriculados e frequentadores de cursos do Centro de Ciências Sociais (CCSo), no ano letivo de 2019, no campus Dom Delgado da Ufma. Onze $(68,75 \%)$ eram do sexo feminino e cinco $(31,25 \%)$ do masculino. Em relação à idade, seis (37,5\%) professores tinham de 37 a 46 anos; três (18,75\%) apresentavam 47 a 56 anos; cinco $(31,25 \%)$ possuíam de 57 a 66 anos e dois (12,5\%) professores com faixa etária de 67 a 76 anos de idade, sendo média das idades de 52.3 anos. Quanto à formação inicial dos professores, sete $(43,75 \%)$ eram formados em Pedagogia; quatro (25\%) professores tinham formação em Comunicação Social e dos outros cinco (31,25\%) cada um era formado em Biblioteconomia, em Direito, Ciências Sociais, História e outro em Informática. 
A pesquisa de campo teve como lócus o CCSo da Ufma, localizado no campus Dom Delgado em São Luís (MA). O referido Centro foi selecionado por apresentar maior quantitativo de alunos com deficiência visual regularmente matriculados em relação aos demais centros da universidade. Optou-se por realizar a pesquisa com todos os cursos do CCSo, com exceção dos cursos de Turismo e Hotelaria, lotados no Complexo Fábrica Santa Amélia no Centro Histórico de São Luís (MA), sendo esses dois cursos excluídos por não estarem localizados no campus Dom Delgado.

Para a coleta de dados foi utilizada a entrevista semiestruturada, sendo uma técnica de coleta de dados muito utilizada nas pesquisas das Ciências Sociais, tendo como principal característica um roteiro com perguntas abertas, o entrevistador segue o mesmo, mas deve estar preparado caso a entrevista mude seu percurso (MAGALHÃES, 2016).

As entrevistas depois de gravadas foram transcritas e sua análise compreendeu três passos reflexivos, a descrição, a redução e a interpretação, tentando buscar a essência da experiência do vivido, no sentido de atender ao significado das falas transcritas. A redução fenomenológica ou eidética é um processo fundamental e rigoroso, orienta-se por uma estratificação gradual, consistindo na ação de colocar entre parênteses a existência das coisas, sendo um processo de deixar de lado a existência para mostrar a essência (RANIERI, 2011).

\section{RESULTADOS E DISCUSSÃO}

Na pergunta sobre "O que é inclusão para você?" percebeu-se que dez (62,5\%) professores (PU1, PU2,PU5, PU6, PU7, PU9, PU11, PU12, PU14, PU15) relataram a concepção de inclusão relacionada à valorização da diversidade humana, compreendendo aspectos relacionados ao acolhimento e à geração de oportunidades para que esses alunos tivessem participação efetiva no âmbito educacional.

A abordagem das concepções dos professores, no que diz respeito à inclusão, estava relacionada a compreendê-la em sua dimensão humana, além da posição social ocupada por ela. Nessa perspectiva, tem-se a pesquisa de Magalhães (2016) na qual o professor deve reconhecer o aluno enquanto ser 
humano, estando aberto para o mundo situado, mas que esteja livre para se atualizar na dimensão do tempo vivido. Nesse sentido, ser docente em uma perspectiva fenomenológica é assumir a sua complexidade, revelando o humano e a sua expressividade.

Nessa perspectiva, concorda-se com Laplane e Batista (2008), quando reafirmaram a necessidade de todos em aprender a conviver e a aceitar as diferenças individuais, valorizando cada pessoa em seus aspectos da diversidade humana tanto no meio social quanto educacional, sendo importante valorizar e garantir o acesso ao conhecimento, aos seus direitos e aos valores culturais e sociais, independentemente de sua condição.

Ressalta-se que os professores tinham uma compreensão de aspectos voltados para a valorização do aluno em sua dimensão humana, uma vez que em seus relatos deixaram clara a necessidade de compreender o aluno, de ofertar as condições necessárias para que ele tivesse seu direito à educação garantido. Isto foi percebido nos relatos de PU1, PU3, PU5, PU9, PU14, quando enfatizaram ser preciso compreender, valorizar, acolher e garantir o direito desses alunos independente de suas especificidades.

Percebeu-se que compreensão, valorização, acolhimento, oportunidade e participação integrada relativas às concepções de inclusão de 10 (dez) professores entrevistados, estavam relacionados à pessoa com deficiência ser reconhecida e valorizada como ser humano diante da diversidade em todas as suas dimensões. Nesse sentido, esse olhar sobre percebê-lo como humano e que deve ser tratado como tal, não é simplesmente inserir a pessoa em um dado contexto, é necessário romper com olhares excludentes. A todo instante, muitas outras identidades, classificações, denominações, e terminologias são criadas, a fim de categorizarem as pessoas. A necessidade de fazer parte de um grupo social, para não viver isolado é algo comum e, por vezes, torna-se necessário como se fosse um oxigênio para manutenção da sobrevivência (ORRÚ, 2017).

Assim, a valorização humana relaciona-se a buscar, compreender e valorizar o outro e parece representar a contramão de como as pessoas geralmente são vistas, onde se ignora o ser enquanto humano, enxergando-o apenas pela capacidade que pode ser medida, deixando de lado os sentimentos e as emoções, que têm importante papel para o desenvolvimento integral de qualquer pessoa. 
Nesse sentido, percebe-se que na sociedade a materialização do que o indivíduo possui, marca a sua identidade como uma matriz biológica, de modo que se ignora a presença de outros componentes históricos e sociais, que constituem a pessoa como um ser singular (ORRÚ, 2017).

$\mathrm{Na}$ categoria garantia de direitos por meio das políticas públicas, seis $(37,5 \%)$ professores tinham a concepção de que o processo de inclusão implicava em fatores relacionados à legislação e às políticas públicas com o intuito de garantir a inclusão desses alunos na universidade. Em se tratando da Educação Superior, o direito ao acesso e à permanência do aluno com deficiência e como são ofertadas as condições necessárias para que de fato a inclusão do mesmo ocorra na universidade, estão pautados em um vasto número de leis, decretos e até políticas de ações afirmativas. Tem-se a Lei de cotas ํㅡ 12.711/2012, a qual estabelece que as IES devem reservar na graduação por curso e turno, vagas para as minorias, bem como alunos oriundos de escolas públicas, autodeclarados pretos, pardos, indígenas e pessoas com deficiência (BRASIL, 2012). Acrescenta-se a Lei Brasileira de Inclusão para fortalecer os direitos fundamentais das pessoas com deficiência, bem como os direitos à vida, à habilitação e à reabilitação, à saúde, à educação, à moradia, ao trabalho, à assistência social, entre outros (BRASIL, 2015).

É nesse sentido que seis $(37,5 \%)$ professores perceberam a inclusão como oriunda de uma legislação, que visa garantir os direitos ao acesso na Educação Superior do aluno com deficiência. Assim, de acordo com Passos (2013), a universidade deve oferecer as condições necessárias para o acesso e a permanência desse aluno, por se tratar de um direito adquirido dessas pessoas na sua condição de cidadania. Desse modo, esse processo deveria ser visto como natural e, também, como um avanço democrático fruto da luta social dessas pessoas. E de tal modo, garantir por meio de ações a participação plena de todos na sociedade.

Na $2^{\text {a }}$ pergunta "Você acredita que ocorra inclusão de alunos com deficiência visual nesta universidade?" Em caso positivo ou negativo, justifique, notou-se que quatorze $(81,25 \%)$ professores acreditavam na existência do processo para inclusão na Ufma. Pereira (2017) em sua investigação, também, notou as ações inclusivas promovidas pela Ufma, existindo um núcleo de acessibilidade com a incumbência de auxiliar o processo de inclusão do aluno com deficiência, desde o seu acesso até 
sua permanência e, para tanto, dispõe de recursos humanos e materiais. Todavia, conforme apontado pelos professores desta pesquisa carece de melhorias.

Concorda-se que a inclusão não é um processo que ocorre rapidamente, pois existe a necessidade de organização e planejamento para que se iniciem os processos direcionados à ela. Para a promoção de ações inclusivas são necessárias modificações na universidade, bem como adaptação arquitetônica, criação de um núcleo de acessibilidade, profissionais para auxiliarem no atendimento educacional aos alunos com deficiência, entre outros fatores. (BREDA, 2013).

Outros três (18,75\%) professores não acreditavam na existência de processo de inclusão legitimado na Ufma, inexistindo a inclusão de alunos com deficiência visual, pois a instituição não dispõe de profissionais para trabalharem com Braille. Em relação a isso, Pereira (2017) pontuou a existência de transcritores, ledores e equipamentos para auxiliar o aluno com deficiência visual no Nuaces. Entretanto, ocorre que muitos professores desconhecem esse serviço e até mesmo o órgão realizador desse apoio, o Nuaces. A Resolução n 121/09, que instituiu o Nuaces na Ufma, estabeleceu que a Coordenação de Interpretação e Tradução do núcleo deve ter a assistência de Técnicos em transcrição Braille (UNIVERSIDADE FEDERAL DO MARANHÃO, 2009).

Diante da pergunta "Se acredita que ocorra a inclusão, você sabe como a mesma é realizada?" Em caso positivo ou negativo, explique, treze $(81,25 \%)$ professores possuíam a concepção de que a inclusão do aluno com deficiência visual na Ufma ocorria por meio de ações inclusivas isoladas, mas não representavam inclusão plena, sendo um processo incipiente e, por isso, não compreendia inclusão legitimada. Tais professores apontaram problemas relacionados à sinalização, aos obstáculos, às dificuldades de adaptação do próprio ambiente da Ufma, pois a estrutura física da mesma e da maioria dos ambientes dela é antiga e mesmo com a tentativa de adequação não tem sido suficiente para promover a acessibilidade arquitetônica. A Lei Brasileira de Inclusão no 13.146/2015, diz que a acessibilidade trata da possibilidade e condição de alcance para utilização, com segurança e autonomia em todos os espaços, e ainda ter acesso à informação, comunicação e aos sistemas de tecnologia (BRASIL, 2015).

Nesse sentido, a investigação de Dantas (2017) observou uma discrepância entre aspectos ressaltados pela LBI e a realidade da Educação Superior, sendo que 
na maioria das vezes, a realidade do aluno com deficiência nesse âmbito de ensino não está de acordo com o que é proposto pelas vias legais, pois as condições de mobilidade desses alunos não estão adequadas, incidindo negativamente sobre o próprio processo de aprendizagem pelo tempo de locomoção necessário para cumprimento de suas atividades acadêmicas, o que também poderá causar inquietações físicas e emocionais nos alunos com deficiência.

Outros dois (12,5\%) professores apresentavam concepções voltadas para a integração do aluno com deficiência visual junto com os outros, mas não se caracterizava como inclusão. Percebeu-se que a inclusão de forma integral não tem ocorrido, pois se fala que a mesma existe, mas devido à falta de elementos essenciais constatou-se que há apenas uma integração desse aluno na Educação Superior. Nessa perspectiva, há oportunidade para o aluno com deficiência visual ingressar na universidade, porém muitas vezes acaba encontrando muitos percalços em sua permanência e que contribuem para a inclusão não ser efetiva. Dessa forma, concorda-se Mantoan (2007) que para a existência da inclusão do aluno seria necessário que a universidade oportunizasse, além do ingresso, as condições adequadas para atender às necessidades desse aluno de forma plena.

Teve-se, ainda, um $(6,25 \%)$ professor com a concepção de que a inclusão do aluno com deficiência visual ocorria por meio do Nuaces, oferecendo o suporte necessário para o desenvolvimento de suas habilidades, reconhecendo o papel importante do núcleo como essencial para a ocorrência da inclusão. Pereira e Chahini (2018) elencaram que o Nuaces promove ações e serviços, dando suporte ao aluno quando ingressa na universidade. Porém, nem todos os professores tinham conhecimento de sua existência e, consequentemente, não havia o suporte necessário a eles, apesar dos esforços do Nuaces para cumprir seus objetivos.

Com a pergunta "Você acredita que realiza inclusão de alunos com deficiência visual nesta universidade?" Em caso positivo ou negativo, justifique, percebeu-se que onze $(68,75 \%)$ professores tinham uma concepção de que realizavam a inclusão, reconhecendo-a como esforço pessoal, mediante iniciativas individuais, pois ao terem esses alunos em suas salas de aula, buscavam individualmente o desenvolvimento de metodologias adequadas.

Segundo Lima (2006), o aluno com deficiência visual tem restrições no que tange à assimilação de conceitos e características, sendo o desenvolvimento desses 
conceitos constituído pela aprendizagem tanto acadêmica quanto social e psicomotora. Por isso, é necessário que o professor compreenda que o aluno poderá precisar de um tempo maior para compreender e desenvolver conceitos.

Levando em consideração o que fora colocado pelos professores sobre existir um esforço para a inclusão do aluno com deficiência visual na Ufma e de Lima (2006) sobre o processo de assimilação do aluno com deficiência visual, Pieczkowski (2014) ressaltou que o professor durante o ensino e a aprendizagem dos alunos com deficiência procura adotar metodologias compatíveis aos mesmos, apesar de apresentar certa ansiedade e desconforto diante dessa situação, motivada pela compreensão de que conhecimento e formação são essenciais para atuação do professor no processo inclusivo.

Entretanto, cinco $(31,25 \%)$ professores não acreditavam que realizavam a inclusão do aluno com deficiência visual na Ufma, devido a fatores como a falta de conhecimento por ausência de formação adequada, condições inadequadas e experiências difíceis ao longo do semestre. No que tange à formação do professor, concorda-se com Pieczkowski (2014) sobre a importância do conhecimento e da formação para atuação do mesmo, sobretudo, quando o aluno com deficiência está inserido em sua sala de aula, tendo a necessidade de o professor apresentar saberes essenciais para fundamentar sua prática educacional.

Chahini (2010) ressaltou que o professor recebe o aluno com deficiência, fica diante de uma situação desafiadora que, na maioria das vezes, não conhece a sua especificidade e nem as estruturas de apoio para lhe oferecer recursos e suportes nesse processo. Tal situação ocorreu com a maioria dos professores desta pesquisa, sendo que diante de uma situação como essa, não conseguiam fazer nem o mínimo por falta de informação e conhecimento. Então, percebeu-se que mesmo com o esforço do professor para realizar atividades inclusivas, existiam fatores externos a ele, concordando-se com Chahini (2010) que existem fatores desfavoráveis apesar dos esforços dos professores.

Em relação à pergunta "Qual sua concepção sobre a inclusão de alunos com deficiência visual na Ufma" inferiu-se que oito (50\%) professores relataram a concepção relacionada ao direito e à acessibilidade, sendo um processo de justiça social norteado pelas políticas de ações afirmativas, no sentido de reparar os direitos das pessoas com deficiência negados historicamente. Sobre o sistema de cotas, 
Pereira (2017) enfatizou que se trata de uma ação política de acesso, que por sua vez busca a democratização da Educação Superior, indo na contramão da sociedade capitalista, onde predomina a homogeneidade e o individualismo com parâmetros de qualidade e sustentação. O sistema de cotas para pessoas com deficiência foi implementado pela Lei no 13.409/2016, estabelecendo que as instituições reservem vagas para pessoas com deficiência nos cursos de níveis técnicos, médio e superior (BRASIL, 2016).

Assim, o que se concluiu dos relatos dos professores e em consonância com a legislação brasileira é que a inclusão compreende um processo, que necessita de uma construção coletiva da sociedade, de modo a destituir-se de preconceitos em relação à pessoa com deficiência, uma vez que ainda existe o olhar de incapacidade sobre essas pessoas (PEREIRA, 2017). Desse modo, as políticas públicas e institucionais vêm garantir e reforçar o direito dessas pessoas como cidadãos perante a sociedade.

Prosseguindo-se, cinco (31,25\%) professores apresentavam a concepção de inclusão de alunos com deficiência visual estava voltada ao potencial cognitivo desses alunos, pois a falta de visão não ocasionava nenhum comprometimento cognitivo. Sendo, assim, tais alunos possuíam capacidade de aprendizagem igual aos outros e de desenvolverem suas potencialidades, sem focar na deficiência. Dessa forma, é necessário garantir a esses alunos o desenvolvimento das suas potencialidades, tirando o foco da deficiência. Considera-se que tal concepção se deve ao fato de que embora o aluno não enxergue, não significa que o mesmo não possa aprender, pois são desenvolvidas outras habilidades para suprir a ausência do sentido da visão, possibilitando a ele assimilar o conteúdo e aprender como qualquer outro aluno. Ressalta-se que apenas três $(18,75)$ professores não responderam ao questionamento sobre a concepção da inclusão dos alunos com deficiência visual.

\section{CONSIDERAÇÕES FINAIS}

Notou-se que os professores entrevistados reconheceram que a Ufma tem realizado ações e esforços voltados para garantir o acesso e a permanência dos alunos com deficiência visual, mas a inclusão ainda é um processo incipiente em 
construção, necessitando de mais ações e de investimentos. Existem, ainda, muitas limitações e dificuldades, sobretudo no tocante à garantia de acessibilidade plena desses alunos.

As concepções dos docentes em relação à inclusão dos alunos com deficiência visual na referida universidade contemplaram o direito ao acesso garantido desses alunos por meio do sistema de cotas, a acessibilidade plena desde o ingresso deles até sua permanência e a garantia para desenvolverem suas potencialidades pelo potencial cognitivo dos mesmos. Dessa forma, esses alunos são incluídos na Ufma, por se tratar de um direito deles de estarem nesse ambiente, conquistado ao longo dos anos, sobretudo, por meio do sistema de cotas e que a mesma deve prover as condições para suas acessibilidades arquitetônica, pedagógica e comunicacional.

Constatou-se que devem existir mais ações, bem como a articulação comunicacional de todas as instâncias da universidade, pois notou-se a ausência dessa articulação quando esses alunos adentravam na universidade, ficando sem o apoio que precisavam, uma vez que seus professores daquele semestre letivo, não eram comunicados com antecedência sobre sua presença para que adequassem metodologias específicas.

A acessibilidade atitudinal, também, foi um elemento importantíssimo para sanar os problemas de inclusão, pois se refere à percepção do outro sem preconceitos, estigmas, estereótipos e discriminações, relacionando-se a todas às outras formas de acessibilidade, sendo necessário a comunidade universitária romper com essa barreira atitudinal para que ocorram melhores possibilidades para a efetivação da inclusão.

Concluiu-se que apesar das ações desenvolvidas e dos serviços oferecidos, há necessidade de adequação em relação às acessibilidades arquitetônica, pedagógica e comunicacional para a efetivação da inclusão de alunos com deficiência visual na Universidade Federal do Maranhão. 


\section{REFERÊNCIAS}

ANSAY, Noemi Nascimento. A inclusão de alunos surdos no ensino superior. Revista do Núcleo de Estudos e Pesquisas Interdisciplinares em Musicoterapia, Curitiba, v. 1, p. 120-136, 2010.

ASSOCIAÇÃO BRASILEIRA DE NORMAS TÉCNICAS. NBR 9050: Acessibilidade a edificações, mobiliário, espaços e equipamentos urbanos. Rio de Janeiro: ABNT, 2004.

BRANDÃO, Carlos da Fonseca. As cotas na Universidade Pública Brasileira: será esse caminho? Campinas: Autores Associados, 2005.

BRASIL. [Constituição (1988)]. Constituição da República Federativa do Brasil de 1988. Brasília, DF: Presidência da República, [2016]. Disponível em: http://www.planalto.gov.br/ccivil_03/Constituicao/Constituiçao.htm. Acesso em: 26 ago. 2019.

BRASIL. Decreto no 10.502, de 30 de setembro de 2020. Institui a Política Nacional de Educação Especial: Equitativa, Inclusiva e com Aprendizado ao Longo da Vida. Diário Oficial da União: seção 1, Brasília, DF, 1 out. 2020.

BRASIL. Decreto no 5.296, de 2 de dezembro de 2004. Regulamenta as Leis $\mathrm{n}^{\mathrm{os}} 10.048$, de 8 de novembro de 2000 , que dá prioridade de atendimento às pessoas que especifica, e 10.098, de 19 de dezembro de 2000, que estabelece normas gerais e critérios básicos para a promoção da acessibilidade das pessoas portadoras de deficiência ou com mobilidade reduzida, e dá outras providências. Diário Oficial da União: seção 1, Brasília, DF, 3 dez. 2004.

BRASIL. Decreto o 7.611, de 17 de novembro de 2011. Dispõe sobre o Atendimento Educacional Especializado, prevendo estruturação de Núcleos de acessibilidade das Instituições Federais de Educação Superior. Diário Oficial da União: seção 1, Brasília, DF, 18 nov. 2011.

BRASIL. Lei no 10.048 , de 8 de novembro de 2000. Dá prioridade de atendimento às pessoas que especifica, e dá outras providências. Diário Oficial da União: seção 1, Brasília, DF, 9 nov. 2000a.

BRASIL. Lei no 10.098, de 19 de dezembro de 2000. Estabelece normas gerais e critérios básicos para a promoção da acessibilidade das pessoas portadoras de deficiência ou com mobilidade reduzida, e dá outras providências. Diário Oficial da União: seção 1, Brasília, DF, 10 dez. 2000b.

BRASIL. Lei no 10.436, 24 de abril de 2002. Dispõe sobre a Língua Brasileira de Sinais - Libras e dá outras providências. Diário Oficial da União: seção 1, Brasília, DF, 25 abr. 2002.

BRASIL. Lei no 12.711, de 29 de agosto 2012. Dispõe sobre o ingresso nas universidades federais e nas instituições federais de ensino técnico de nível médio e dá outras providências. Diário Oficial da União: seção 1, Brasília, DF, 30 ago. 2012. 
BRASIL. Lei no 13.146, de 6 de julho de 2015. Lei Brasileira de Inclusão da Pessoa com deficiência (Estatuto da Pessoa com deficiência). Diário Oficial da União: seção 1, Brasília, DF, 7 jul. 2015.

BRASIL. Lei no 13.409, de 28 de dezembro de 2016. Altera a Lei no 12.711, de 29 de agosto de 2012, para dispor sobre a reserva de vagas para pessoas com deficiência nos cursos técnico de nível médio e superior das instituições federais de ensino.

Diário Oficial da União: seção 1, Brasília, DF, 29 dez. 2016.

BRASIL. Lei no 9.394, de 20 de dezembro de 1996. Estabelece as diretrizes e bases da educação nacional. Diário Oficial da União: seção 1, Brasília, DF, 23 dez. 1996a.

BRASIL. Ministério da Educação. Aviso Circular n² 277/MEC/GM. Brasília, DF: Ministério da Educação, 8 maio 1996b. Assunto: Política educacional dirigida aos portadores de necessidades especiais.

BRASIL. Ministério da Educação. Portaria n. 1.679, de 2 de dezembro de 1999. Dispõe sobre requisitos de acessibilidade de pessoas portadoras de deficiências, para instruir os processos de autorização e de reconhecimento de cursos, e de credenciamento de instituições. Brasília, DF: MEC, 1999.

BRASIL. Ministério da Educação. Portaria no 3.284, de 7 de novembro de 2003. Dispõe sobre requisitos de acessibilidade de pessoas portadoras de deficiências, para instruir os processos de autorização e de reconhecimento de cursos, e de credenciamento de instituições. Brasília, DF: MEC, 2003.

BRASIL. Ministério da Educação. Secretaria de Educação Especial. Política Nacional de Educação Especial na Perspectiva Inclusiva de 2008. Brasília, DF: MEC, 2008.

BREDA, Davieli Chagas. A inclusão no ensino superior: um estudante surdo no programa de Pós-Graduação em educação. 2013. 182 f. Dissertação (Mestrado em Educação) - Universidade Federal do Espírito Santo, Centro de Educação, Vitória, 2013.

CABRAL, Leonardo Santos Amâncio. Inclusão do público-alvo da Educação Especial no Ensino Superior brasileiro: histórico, políticas e práticas. Revista de Educação da PUC, Campinas, v. 22, n. 3, p. 371-387, 2017.

CABRAL, Leonardo Santos Amâncio. Políticas de ações afirmativas, pessoas com deficiência e o reconhecimento das identidades e diferenças no ensino superior brasileiro. Arquivos Analíticos de Políticas Educativas, Arizona, v. 26, n. 57, p. 133, 2018.

CABRAL, Leonardo Santos Amâncio; MELO, Francisco Ricardo Lins Vieira de. Entre a normatização e a legitimação do acesso, participação e formação do público-alvo da educação especial em instituições de ensino superior brasileiras. Educar em Revista, Curitiba, v. 33, n. 3, p. 55-70, dez. 2017. Número especial. 
CARDOSO, Mariana. Educação especial e inclusiva: caminhos percorridos. Democratizar, Rio de Janeiro, v. 6, n. 2, p. 1-9, ago./dez. 2012.

CARVALHO, Rosita Edler. Educação inclusiva: com os pingos nos "is". 3. ed. Porto Alegre: Mediação, 2004.

CAVALCANTE, Claudia Valente. Políticas de ação afirmativa na educação superior brasileira: uma análise dos planos nacionais de educação 2001-2010 e 2014-2024: uma estratégia para a redução das desigualdades sociais e escolares? Poiésis, Tubarão, v. 9, n. 16, p. 333-350, jul./dez. 2015.

CERQUEIRA, Jonir Bechara; FERREIRA, Elise de Melo Borba. Recursos didáticos na educação especial. [Brasília, DF]: IBC, 2000.

CHAHINI, Thelma Helena Costa. Atitudes sociais e opiniões de professores e alunos da Universidade Federal do Maranhão em relação a inclusão de alunos com deficiência na Educação Superior. 2010. 132 f. Tese (Doutorado) Faculdade de Filosofia e Ciências, Universidade Estadual Paulista, Marília, 2010.

CHAHINI, Thelma Helena Costa. Atitudes sociais e opiniões de professores e alunos da universidade federal do maranhão em relação à inclusão de alunos com deficiência na educação superior. Curitiba: Instituto Memória Editora e Projetos Culturais, 2013. v. 200.

CHAHINI, Thelma Helena Costa. O percurso da inclusão de pessoas com deficiência na Educação Superior. Curitiba: Appris, 2016.

CHAHINI, Thelma Helena Costa. Políticas afirmativas para o acesso de alunos com deficiência à educação superior. In: CARVALHO, M. W. B. de; COSTA, V. A. da;

MIRANDA, T. G. (orgs.). Educação, educação superior e inclusão escolar: pesquisas, experiências e reflexões. Niterói: Intexto, 2012. p. 157-168.

COSTA, Maria Sanchez da. Sentimentos de professores frente às dificuldades na prática da Educação Inclusiva de alunos com deficiência no ensino fundamental. 2007. 121 f. Dissertação (Mestrado em Psicologia da Educação) Pontifícia Universidade Católica de São Paulo, São Paulo, 2007.

COUTINHO, Bertran Golçaves. Inclusão social da pessoa com deficiência física: fatores relacionados à inclusão e permanência no mercado de trabalho. 2012. $79 \mathrm{f}$. Dissertação (Mestrado em Ciência e Saúde Pública) - Programa de Pós-Graduação em Saúde Pública, Universidade Estadual da Paraíba, João Pessoa, 2012.

COUTINHO, Márcia Maria de Azeredo. A inclusão da pessoa com deficiência visual na educação superior e a construção de suas identidades. 2011. 104. F. Dissertação (Mestrado) - Universidade Católica Dom Bosco, Campo Grande, 2011.

DANTAS, Nozângela Maria Rolim. A inclusão dos estudantes com deficiência no centro de formação de professores da universidade Federal de Campina Grande: desafios e possibilidades. 2017. 248 f. Tese (Doutorado) - Programa de 
Pós-Graduação em Educação, Pontifícia Universidade Católica do Rio Grande do Sul, Porto Alegre, 2017.

DIAS, Maria B. Ações afirmativas: uma solução para a desigualdade. BuscaLegis, Florianópolis, 2002. Disponível em:

http://egov.ufsc.br/portal/sites/default/files/anexos/15893-15894-1-PB.pdf. Acesso em: 10 jun. 2018.

DOURADO, Luiz Fernandes; CATANI, Afrânio Mendes; OLIVEIRA, João Ferreira. Políticas públicas e reforma da educação superior no Brasil: impasses e perspectivas. Proposições, Campinas, v. 15, n. 3, p. 91-115, dez. 2004.

FACHINETTI, Tamiris Aparecida. Visão docente de alunos com deficiência sobre a inclusão na Educação Superior. 2018. 108 f. Dissertação (Mestrado em Educação Escolar) - Universidade Estadual Paulista "Júlio de Mesquita Filho" Faculdade de Ciências e Letras, Araraquara, 2018.

GIROTO, Claudia Regina Mosca; POKER, Rosimar Bortolini; OMOTE, Sadao. As tecnologias nas práticas pedagógicas inclusivas. Marilia: Cultura Acadêmica, 2012.

JESUS, Ivone das Dores de. A inclusão de alunos com deficiência na educação superior: uma análise na Universidade Estadual do Maranhão. 2020. 98 f. Tese (Doutorado em Educação) - Universidade Federal da Grande Dourados, Dourados, 2020.

JESUS, Ivone das Dores de. Analisando a educação inclusiva no curso de Licenciatura em Geografia da Universidade Estadual do Maranhão. 2012. 97 f. Dissertação (Mestrado em Educação) - Programa de Pós-Graduação em Educação da Universidade Federal do Maranhão, São Luís, 2012.

KLÜBER, Tiago Emanuel; BURAK, Dionísio. A Fenomenologia e suas contribuições para a educação matemática. Práxis Educativa, Ponta Grossa, v. 3, n. 1, p. 95 -99, jan./jun. 2008.

LAPLANE, Adria Lia Friszman de; BATISTA, Cecilia Guarneiri. Ver não ver e aprender: a participação de crianças com baixa visão e cegueira na escola.

Cadernos CEDES, Campinas, v. 28, n. 75, p. 209-227, maio/ago. 2008.

LIMA, Priscila Augusta. Educação inclusiva e igualdade social. São Paulo: Avercamp, 2006.

MAGALHÃES, Carla Nery. A docência no ensino superior: um olhar fenomenológico a partir da percepção dos professores da Universidade Federal de Sergipe. 2016. 140 f. Dissertação (Mestrado) - Programa de Pós-Graduação em Educação, Universidade Federal de Sergipe, São Cristóvão, 2016.

MAGALHÃES, Rita de Cássia Barbosa Paiva. Ensino superior no Brasil e inclusão de alunos com deficiência. In: VALDÉS, Maria Teresa Moreno (org.). Inclusão de pessoas com deficiência no ensino superior no Brasil: caminhos e desafios. Fortaleza: EDUECE, 2006. p. 39-55. 
MANTOAN, Maria Teresa Egler. 0 desafio das diferenças nas escolas. Petrópolis: Vozes, 2007.

MANZINI, Eduardo José. Acessibilidade: um aporte na legislação para o aprofundamento do tema na área de educação. In: BAPTISTA, Claudio Roberto; CAIADO, Katia R. M.; JESUS, Denise M de. (orgs.). Educação especial: diálogo e pluralidade. Porto Alegre: Mediação, 2008. p. 281-289.

MASINI, Elcie Aparecida Fortes; BAZON, Fernanda Vilhena Mafra. A inclusão de estudantes com deficiência, no ensino superior. In: REUNIÃO ANUAL DA ANPED, 28., 2005, Caxambu. Anais GT 20 - Psicologia da Educação [...]. Caxambu: Anped, 2005.

MATTOS, Edina Antônia de. Deficiente mental: integração/inclusão/exclusão. Revista Videtur, São Paulo, Mandruvá, v. 13, p. 13-20, 2002.

MOREIRA, Laura Cereta. Políticas inclusivas no ensino superior: da implantação à concretização. In: MENDES, Enicéia Gonçalves; ALMEIDA, Maria Amélia de (orgs.). Dimensões pedagógicas nas práticas de inclusão escolar. Marília: ABPEE, 2012. p. 97-108.

OLIVEIRA, Antônia Soares Silveira e. Alunos com deficiência no ensino superior: subsídios para a Política de Inclusão da Unimontes. 2011. 206 f. Tese (Doutorado em Educação Especial) - Universidade Federal de São Carlos, São Carlos, 2011.

ORRÚ, Sílvia Ester. O re-iventar da inclusão: os desafios da diferença no processo de ensinar e aprender. Petrópolis: Vozes, 2017.

PANIZZI, Wrana Maria. Apresentação. In: UNIVERSIDADE FEDERAL DO RIO GRANDE DO SUL. Valorizando a diversidade. Porto Alegre: UFRGS, 2004.

PASSOS, Ester dos. 0 trabalho docente junto a alunos com deficiência nos cursos de licenciatura. 2013. 128 f. Dissertação (Mestrado em Educação) Universidade da Região de Joinville, Joinville, 2013.

PEREIRA, Josenilde Oliveira. Políticas institucionais de acessibilidade na educação superior: percursos e desafios para a inclusão de alunos com deficiência na UFMA. 2017. 217 f. (Dissertação Mestrado) - Programa de Pós-Graduação em Educação, Universidade Federal do Maranhão, São Luís, 2017.

PEREIRA, Josenilde Oliveira; CHAHINI, Thelma Helena Costa. Núcleos de acessibilidade: expressão das políticas nacionais para a Educação Superior. Curitiba: Appris, 2018.

PEREIRA, Marilú Mourão. Ações afirmativas e a inclusão de alunos com deficiência no Ensino Superior. Ponto de Vista, Florianópolis, n. 10, p. 19-38, 2008.

PIECZKOWSKI, Tania Mara Zancanaro. Inclusão de estudantes com deficiência na educação superior: efeitos na docência universitária. 2014. 208 f. Tese 
(Doutorado em Educação) - Programa de Pós-Graduação em Educação, Universidade Federal de Santa Maria, Santa Maria, 2014.

PIMENTA, Cláudia Marisa Ferreira Machado. Acesso e permanência de estudantes com deficiência visual em uma Instituição de Ensino Superior. 2017. 239 f. Tese (Doutorado) - Faculdade de Educação, Universidade Federal da Bahia, Salvador, 2017.

PINHEIRO, Joice Fernanda. Desafios e concepções dos professores do Centro de Ensino Paulo VI para a Educação Inclusiva. 2017. 75 f. (Monografia de Graduação) - Universidade Estadual do Maranhão, São Luís, 2017.

PROGRAMA DAS NAÇÕES UNIDAS PARA O DESENVOLVIMENTO. Relatório de desenvolvimento humano: racismo, pobreza e violência. Brasília, DF: Pnud, 2005. RAMA, Claudio. Las personas com discapacidades: los excluídos de las Educacion Superior em América Latina y el Caribe. In: VALDÉS, Maria Teresa Moreno (org.). Inclusão de pessoas com deficiência no ensino superior no Brasil: caminhos e desafios. Fortaleza: Eduece, 2006. p. 39-55.

RANGEL, Aline Batista. Inclusão de pessoas com deficiência na Universidade Federal Fluminense: acesso e permanência, possibilidades e desafios. 2015. Dissertação (Mestrado em Educação) - Universidade Federal Fluminense, Rio de Janeiro, 2015.

RANIERI, Leandro Penna. Dimensões existenciais do esporte: fenomenologia das experiências esportivas de atletas com deficiência visual. 2011. 125 f. Dissertação (Mestrado) - Escola de Educação Física e Esporte, Universidade de São Paulo, São Paulo, 2011.

ROCHA, Telma Brito; MIRANDA, Theresinha Guimarães. A inclusão de alunos com deficiência no ensino superior: uma análise de seu acesso e permanência. In: DIAZ, Félix et al. (orgs.). Educação inclusiva, deficiência e contexto social: questões contemporâneas. Salvador: EDUFBA, 2009. p. 27-37.

SILVA JÚNIOR, Bento Selau da; HAMMES, Lúcio Jorge. Inclusão de cegos na Educação Superior: algumas estratégias para superação de obstáculos. In: ENCONTRO DA ASSOCIAÇÃO NACIONAL DE PÓS-GRADUAÇÃO E PESQUISA EM EDUCAÇÃO SUL, 10., 2014, Florianópolis. Anais eletrônicos [...]. Florianópolis: ANPEd, 2014.

SOARES, Ana Cristina Silva. A inclusão de alunos com deficiência visual na Universidade Federal do Ceará: ingresso e permanência na ótica dos alunos, docentes e administradores. 2011. 237 f. Tese (Doutorado em Educação) Programa de Pós-graduação em Educação Brasileira, Universidade Federal do Ceará, Fortaleza, 2011.

UNIVERSIDADE FEDERAL DO MARANHÃO. Conselho de Pesquisa e Extensão. Resolução no 499, de 31 de outubro de 2006. Trata da Política de Cotas adotada pela UFMA a partir do segundo semestre de 2007. São Luís: Ufma, 2006. 
UNIVERSIDADE FEDERAL DO MARANHÃO. Conselho Universitário. Resolução no 121, de 17 de dezembro de 2009. Aprova a criação do Núcleo Pró Acessibilidade e Permanência de Pessoas com Deficiência à Educação. São Luís: Ufma, 2009.

UNIVERSIDADE FEDERAL DO MARANHÃO. Plano de Desenvolvimento Institucional 2017- 2021. São Luís: Ufma, 2016. 